\title{
Analysis on Importance of Traditional Chinese Culture in Personality Molding among College Students
}

\author{
Lei WANG ${ }^{1, a,{ }^{*}}$ \\ ${ }^{1}$ Linyi University, Feixian, Shandong, China \\ alyulgc@126.com
}

Keywords: Personality molding of college students, Traditional culture, Traditional moral spirits.

\begin{abstract}
The current moral situation is mixed, of which the mainstream is positive and good, while there are also some noticeable problems which has influenced the personality molding of college students. Therefore, the educators must take positive attitude to draw strength from traditional Chinese culture in a scientific way, then to cultivate new persons who have $t$ heir own ideals, value morality and are able to combine knowledge with actions. It will have uncountable positive significance on the development of contemporary college students, and play important role in the personality cultivation of college students as well.
\end{abstract}

\section{Introduction}

Traditional Chinese culture is the moral quality and patrimony that formed in the long-term history of Chinese nation and has been passed down from generation to generation, is composed of national character, national spirit, national integrity, national emotion and national profit[1].By absorbing certain culture, the personality molding, means to select, construct, cultivate, perfect and create different features of personality on different types of current people, thus to weaken the negative factors of personality, and enlarge excellent traits or other positive factors, to form modern personality pattern that will enhance the progress of social civilization. China is in the period of social transformation, along with the overall implementation of marketeconomy, the merging with exotic culture. All above makes that all kinds of social concepts are mixed together, restlessness has become the common social attitude, which is shown on the contemporary college students especially obviously.

\section{Current Moral Situation of College Students}

The mainstream of current morality of college students is good and positive. Majority of college students praise the basic moral principles like honesty, integrity, fairness, devoting and hard working, hope to build a fair, impartial and effective society. They would like to equip themselves with noble moral quality and sound personality, they tend to respond strongly to the immoral social phenomena, and come to recognize and judge themselves more objectively, and have strengthened the crisis consciousness and competitiveness. However, for the college students themselves, there are some noticeable problems existing in their moral situations:

Gradual blurring moral concepts. Newly entering the university, quite a few students dislike their major during the study, prefer thinking to talking, got lost and confused in the complicated society, can't distinguish right from wrong, good from evil. Such 
phenomenon resulted from various reasons, while the major reason is the deviation in individual values and self-position of society.

Dual criteria on moral evaluation. Take more consideration on themselves than on others, more on rights than on duties, hold higher standard on others than on oneself.

The deviation of students' moral behavior comes from their moral cognition. The outstanding aspect is that college students cannot take the lead to start from themselves.

Lower standard on moral pursuit. College students confine the coordination function of morality to social relationships and personal relationships, while ignoring the function of moral persuasion on purifying mind and improving morality.

From above, the key for college students to adapt to society and gain their own is molding the positive and harmonious personality.

\section{Traditional Chinese Culture is very Important for the Personality Molding among College Students}

The development and progress of Chinese history is rooted in traditional Chinese culture. Among it, with the development and blending of Confucianism, Taoism and Buddhism, many brilliant cultural heritages has been left on moral consciousness, thinking characteristics and values. The transmission and popularization of valuable parts of traditional culture will have positive influence on college students, will have a certain realistic significance for reconstructing humanism spirit of college students, for the harmony and progress of society as well. Combined with excellent traditions of Chinese culture, here I think we could explore the relations between traditional culture and the personality molding of contemporary college students from following aspects.

\section{Traditional Chinese Culture is the Inexhaustible Source of Moral Education}

The excellent traditional culture of Chinese nations plays an important and non-fungible role on the moral education of colleges and universities. The Confucianism, Taoism and Buddhism in Chinese all emphasize the improving and perfection of the moral quality of people, and has distinct ethics color[2]. One of the aim of learning traditional Chinese culture and carrying out quality education is building up students' right morals, right philosophy and value of life. Especially the Confucian culture, which itself centered on ethical and moral values. The reason why intellectuals of overseas cultural circles attach great attention to traditional Chinese culture is exactly the prominent humanism spirit among it.

\section{Traditional Chinese Culture Benefits the Expansion of Knowledge of College Students}

According to Qian-Xuesen, the famous scientist who creative thought generates from the cross-penetration of both knowledge and way of thinking of different disciplines. Einstein once pointed out clearly: "we can obviously regard philosophy as the mother of all scientific studies, if we view philosophy as the pursuit of knowledge in the most common and extensive way" [3]. The Confucianism, Taoism and Buddhism of Chinese culture belongs to different systems of philosophy, the quality education we carrying out currently is a combination of moral quality education and cultural quality education. Studying traditional Chinese culture is an important way to enlarge knowledge, and promote the comprehensive quality of college students. Thus it can be seen that traditional Chinese culture plays a common guidance role on scientific studies. 


\section{Traditional Chinese Culture Benefits the Change of Thinking Mode of College Students}

There is inherent regularity in scientific thoughts, the development of thoughts will surely grow into a certain logic structural frame, and will construct certain ideas system as well. The significance of learning the thinking mode of traditional culture is that we can explore the inherent law systems of development of science, and construct scientific ideas system. The mode of thinking reflects both the culture and quality [1].One of the aim of studying traditional Chinese culture is to learn the thinking mode of ancient people, thus to seek the ways to solve problems. To master the integration thinking, dialectical thinking, intuition thinking, neutral thinking and image thinking in traditional Chinese culture, is an important channel for contemporary college students to expand their thinking.

\section{Traditional Chinese Culture Benefits the Cultivation of Innovative Spirit of College Students}

Reform and innovation are invariable force of social and national development. In the long course of Chinese history, we once has a period filled with conformism and complacency, but for the overall development of history, there are also people dissatisfied with the status quo, there are spirits of innovation, thoughts on reform and ideas seeking for national prosperity keep emerging through the whole history of our nation. All above are not only motivation to the continuous innovation and people's stepping into new era of life, but also are guiding philosophy that can promoting the continuous progress of society. The current society is innovation-centered society; innovation determines the prospect of a nation as well. Currently speaking, innovative ability is one of the most necessary qualities of talents. Therefore, carrying forward innovative spirit and cultivating such spirit from the realistic society are the key for contemporary college students to adapt themselves to society, and the key to national rejuvenation as well.

\section{Traditional Chinese Culture Benefits the Cultivation of Self-reliance Spirit of College Students}

Based on active attitude toward society and Confucianism promising, the Confucian school emphasizes running the life with positive social psychology, people's initiative will change the reality and propel the development o society. When confronting hardships, it is essential for us to exert subjective initiative, change the mentality, trapped in the environment temporarily and then create new environment, and cultivate spirit of being promising as well as self-reliance. For contemporary college students, being promising and self-reliance is the quality firstly needed. The spirits of self-reliance and perseverance and "never say die" are the stepping stones for college students to success. Through bettering characters, we can confront setbacks and rise in adversity, then reshape the life. Despite the improvement of oneself, we also need the progress of society correspondingly, and the traditional culture fills the ideal value vacuum exactly. To setup right enterprising spirit and self-reliance spirit, contemporary college students must absorb the essence of traditional culture, and find the exact position of them from the development skeleton of traditional culture, and establish the positive personality in the process of conquering hardships and setbacks. 


\section{Traditional Chinese Culture Helps College Students to Balance the Relations between Justice and Profits}

In the semi-socialized campus, college students are more easily influenced by the utilitarianism, with which students will focus only on personal profits, and even sacrifice the profits of others or of society for theirs, in the end, both society and students themselves will get harmed. So facing with the social reality of material desire overflow, college students should put first emphasis on the sense of social justice and social responsibility, stick to the principle of " refrain from some things in order to accomplish other things" and the criterion of justice. Besides, college students should influence and reconstruct new moral thoughts in contemporary utilitarian society with their conscious effort. As a saying goes, a gentleman makes money through honorable means. We should build up new concept of utility, and focus on the unity of utility and morality.

\section{Traditional Chinese Culture Benefits the Healthy Psychological Development of College Students}

The change of society, increasing pressure of competition, and imperfect realization of oneself has caused mental problems among more and more college students. To solve the problem essentially, we must study and use the concept of harmony in traditional culture, help college students to play their initiative, perfect their intelligence, maintain harmonious mind, regulate their psychology well, and maintain a sense of balance in study and life, thus help them to improve and perfect their own personality fundamentally.

\section{Summary}

Modern social civilization calls out for the improvement on quality of people. The modernization of Chinese society, on the aspect of spirit substance, is the modernization of people. For a nation, without humanism spirit centered around people's ideal and morality, without modernization in real sense [5]. Cultivating and bringing up talents with high quality is the basic task for higher education. Culture determines the basic characteristics of personality, for college students, it is necessary to absorb the essence of traditional culture actively, thus truly accomplish the self-correction and self-molding of personality in social practice. As a result, they will adapt to the society better, reform the society better, accomplish their historical mission as contemporary youth.

\section{References}

[1] Zhang Xiyue, The Analysis on Current Situation of Professional Quality of University Counselors and Research on Countermeasures [J]. Journal of Chifeng University (Science Education Edition), 2011.

[2] Hu Guilu, Thoughts about Moral and Ethical Conditions of Contemporary College Students [J].Social Science Forum, 2005, (4).

[3] Zhang Weiqiang, Traditional Chinese Culture and Moral Education of Colleges [J]. China Market, 2007, (1). 
[4] Chen Wenbin, Liu Jingwei, Gong Liyan, Thoughts about Strengthening the Education of Traditional Chinese Culture for College Students [J]. Education Exploration, 2005, (7).

[5] Ji Derong, Li Wei, Tian Jun, Research on Moral and Traditional Education Status of College Students [J].New West, 2007,(2). 